\title{
Diversity of the Land Resources in the Amazonian State of Rondônia, Brazil
}

\author{
T.T. COCHRANE, Thomas. A. COCHRANE ${ }^{1}$
}

\begin{abstract}
Conflicting opinions are recorded in the literature concerning the suitability of Amazon lands for sustainable agriculture following deforestation. This article has been written to shed light on this question by summarizing climate, landform, soil and vegetation features from the findings of a land resource study of the Brazilian state of Rondônia in south-west Amazonia. The work, which followed the World Soils and Terrain Digital Database (SOTER) methodology, was financed by the World Bank. During the course of the survey special emphasis was given to studying soils; 2914 profiles were analyzed and recorded. The study identified a complex pattern of land units with clear differences in climate, landform, soils and native vegetation. Forested areas mosaic with lesser areas of natural savannas. The latter occur on both poorly-drained and well-drained, albeit nutrient deficient sandy soils. The tallest and most vigorous forests or their remnants were seen growing on well-drained soils formed from nutrient-rich parent materials. Many of these soils could, or are being used for productive agriculture. Soils developed on nutrient-poor parent materials support forests that are significantly lower in height, and would require large lime and fertilizer inputs for agriculture. Low forests with high palm populations and minor areas of wet land savannas cover the poorly drained soils. It is evident that forest clearing in the past was indiscriminant; this cannot be condoned. The diversity of land conditions found throughout Rondônia would suggest that many past studies in the Amazon have simply been too broad to identify significant soil differences.
\end{abstract}

\section{KEYWORDS}

soils, Rondônia, land resources, fertility

\section{Diversidade dos terrenos e solos do estado de Rondônia, Brasil}

\begin{abstract}
RESUMO
Opiniões divergentes são encontradas na literatura com respeito ao uso de terras da Amazônia para agricultura sustentável apos desmatamento. Este artigo busca clarificar a questão com um resumo dos resultados de um estudo dos recursos naturais (clima, atributos de solos e terrenos, e vegetação) do estado de Rondônia. O trabalbo seguiu a metodologia do World Soils and Terrain Digital Database (SOTER) e foi financiado pelo banco mundial. Durante a fase de investigação no campo, concentrouse no estudo de solos onde 2914 perfis de solos foram analisados. O estudo mostra que Rondônia tem um mosaico complexo de unidades de terra com diferenças claras em clima, terrenos, solos e vegetação nativa. Observa-se a combinação de florestas, que originalmente predominaram na região, com savanas naturais mal drenadas e outras savanas bem drenadas mas pobres em nutrientes. Asflorestas mais altas e vigorosas podem ou podiam ser encontradas crescendo em solos bem drenados derivados de materiais paternos ricos em minerais. Muitos desses solos podem ser, ou estão sendo, utilizados para agricultura produtiva. Solos derivados de materiais paternos pobres em nutrientes suportam bosques baixos e requerem grandes quantidades de cale fertilizante para agricultura. Por outro lado, bosques baixos com altas populações de palmeiras e pequenas áreas de savanas úmidas cobrem solos mal drenados. É evidente que o desmatamento da floresta no passado foi indiscriminado e isto não pode ser justificado. A variabilidade de solos encontrados em Rondônia indica que os estudos de terrenos e solos realizados na Amazônia ate o momento têm sido muito gerais para que se possa detectar variações significativas nos solos.
\end{abstract}

\section{PALAVRASCHAVE}

Solos, Rondônia, recursos naturais, fertilidade

\footnotetext{
${ }^{1}$ Thomas A. Cochrane, College of Engineering, Department of Civil Engineering, University of Canterbury, Private Bag 4800, Christchurch 8020, New Zealand. E-mail: tom.cochrane@canterbury.ac.nz
} 


\section{ACTA \\ AMAZONICA}

DIVERSITY OF THE LAND RESOURCES IN THE AMAZONIAN STATE OF RONDÔNIA, BRAZIL. DIVERSIDADE DOS TERRENOS E SOLOS DO ESTADO DE RONDÔNIA, BRASIL.

\section{INTRODUCTION}

Public awareness has long been focused on the Amazon forests of tropical South America due to concern over the assumed effects of deforestation on the earth's climate, loss of bio-diversity and land degradation. While the relative effect of deforestation on climate may be debated, loss of bio-diversity is undoubtedly a serious concern. With respect to land degradation following deforestation, apart from the evident erosion hazards for rolling and hilly terrain and river pollution, many past authorities considered Amazon "forest soils" incapable of sustaining agricultural or livestock production after the primary vegetation is removed (Tosi, 1974, Budowski, 1976, Goodland and Irvine 1976, Irion 1978, and many others). Data from a relatively detailed survey of the land conditions of the south-west Brazilian Amazon state of Rondônia is used to shed light on this question. The region was opened up for more intensive human occupation in recent times with the unfortunate consequence of the devastation of extensive areas of native forests. The state of Rondônia extends over approximately 24,000,000 ha of the south-west Amazon.

Agricultural colonization has proceeded apace in Rondônia over the past 25 years following the construction of the allweather BR-364 highway linking the states of Mato Grosso, Rondônia and Acre with the rest of the country. This highway has provided a valuable alternative corridor for the export of agricultural and forestry products, and minerals to European and North American markets from south-western Amazonia and North Mato Grosso, via the port city of Porto Velho, the capital of Rondônia on the Madeira river. The latter is a major tributary of the Amazon river, and is navigable by large (over 2000 ton capacity) barges between Porto Velho and Manaus, where produce can be trans-shipped to ocean-going vessels; this is a situation not unlike the Great Lakes - St. Laurence seaway of north America. The new road has resulted in the opening up of a large part of the region. Colonization has resulted in the indiscriminant deforestation of large tracts of land.

To address this situation and other development issues, the government of Rondônia commissioned a somewhat tardy study titled the "Segunda Aproximação do Zoneamento SócioEconômico Ecológico do Estado do Rondônia ZEE-RO" (Second Approximation of the Ecological and Socio-economic Zoning project). The technical objective of that project was to improve the zoning of the land of Rondônia in order to encourage and implement ecologically sound development and conservation policies. It was to provide an unbiased technical assessment of the present state of Rondônian lands, and establish a "benchmark" for the future evaluation. The study was financed by the World Bank through BIRD Loan Agreement 3444-Br. The corner stone of that study was considered to be a soils and terrain land resource survey of the state. The senior author was contracted to lead a team to carry out this survey.

The purpose of the present article is to provide a brief summary of the land conditions found throughout Rondônia in order to draw attention to the significant variations in climate, landforms, parent materials, soils and natural vegetation found throughout that area of the Amazon. The specific objective of the analysis is to answer the perennial question of the suitability or otherwise of Amazon forest lands for sustainable agricultural and pastoral usage.

\section{MATERIALS AND METHODS}

The fundamental approach to evaluating the lands of Rondônia was an adaptation of the Australian "Land Systems" methodology (Christian and Stewart, 1953), as refined for digitization by the International Soil Science Society's initiative, the World Soils and Terrain Digital Database SOTER, project (van Engelen and Wen, 1995). The latter followed on from the work of Cochrane (1980) and Cochrane et al. (1985), in their computerized land system study covering tropical America including Amazonia, which has recently been re-digitized for use in Personal Computers (Cochrane et al. 2003).

\section{The Mapping of Soils and Terrain Units}

Land as seen in the field was mapped as land units, defined for the Rondônian study as: "areas of land with distinctive, often repetitive patterns of climate, landform, lithology, land surfaces, parent material, soils and native vegetation". These land units were termed SOTRO Units (Soils and Terrain units of Rondônia), and are equivalent to the SOTER land units (Soils and Terrain units) of the World Soils and Terrain Digital Database initiative, except they include climate in their delineation. They formed the geographic base for visualizing and comparing land characteristics and differences throughout the state. SOTRO land units were delineated directly onto geo-referenced, satellite imagery at the 1:250,000 scale following field studies.

SIGTERON, the Geographical Information System of the Land Resources of Rondônia

From the outset, the work was systematized through the development of a soils and terrain digital database to describe the characteristics or "attributes" of the SOTRO land units, termed the SOTERON (Soils and Terrain units of Rondônia), which was integrated with a Geographical Information Systems, GIS. The attribute database followed the International Soil Science Society's ISSS, SOTER project criteria. It was expanded by integrating the FAO-ISRIC-CSSS Multilingual Soil (profile) Database, SDBm (1995) and supplemented with other database files, including climate and agricultural suitability. During the course of the study many representative soil profiles were sampled and their locations and analyses recorded in the database. The soils and the numerous thematic maps of Rondônia were generated by linking the map unit files with selected information from the attribute database.

An operational manual for the computerized study was written, and the system was put in place at the start of the project to provide the necessary standardization for carrying 


\section{ACTA \\ AMAZONICA}

DIVERSITY OF THE LAND RESOURCES IN THE AMAZONIAN STATE OF RONDÔNIA, BRAZIL. DIVERSIDADE DOS TERRENOS E SOLOS DO ESTADO DE RONDÔNIA, BRASIL. out the routine land and soil evaluation work in the field, and to monitor progress. The methodology of the approach is detailed in the SIGTERON ("Sistema de Informacão Geografica para os Terrenos e Solos do Estado de Rondônia, Brasil" - the Geographical Information System of the Terrain and Soils of the State of Rondônia, Brazil) manual (Cochrane and Cochrane 1998). A digital copy of the SIGTERON PC Users Packet, together with the final written report on the land resource study of Rondônia, was subsequently annexed to the manual, as CDs. The methodology of the study has been summarized by Cochrane and Cochrane (2001).

The principal inter-linked databases of the SIGTERON system, as illustrated in Figure 1, are:

a) The SOTERON relational database files consisting of a series of files to describe the many land and soil attributes, of the SOTRO units.

b) A series of map files based on the mapped SOTRO Units. These were produced in formats compatible with both the low-cost IDRISI software and the higher cost Arc/Info software.

c) A soil profile database using the FAO-ISRIC-CSIC, Multilingual Soil (profile) Database, SDBm (1995). The latter was modified for the conditions of Rondônia's tropical soils, and to facilitate the printing of soil profile descriptions in Portuguese.

d) Land suitability, meteorological data and other sets of files.

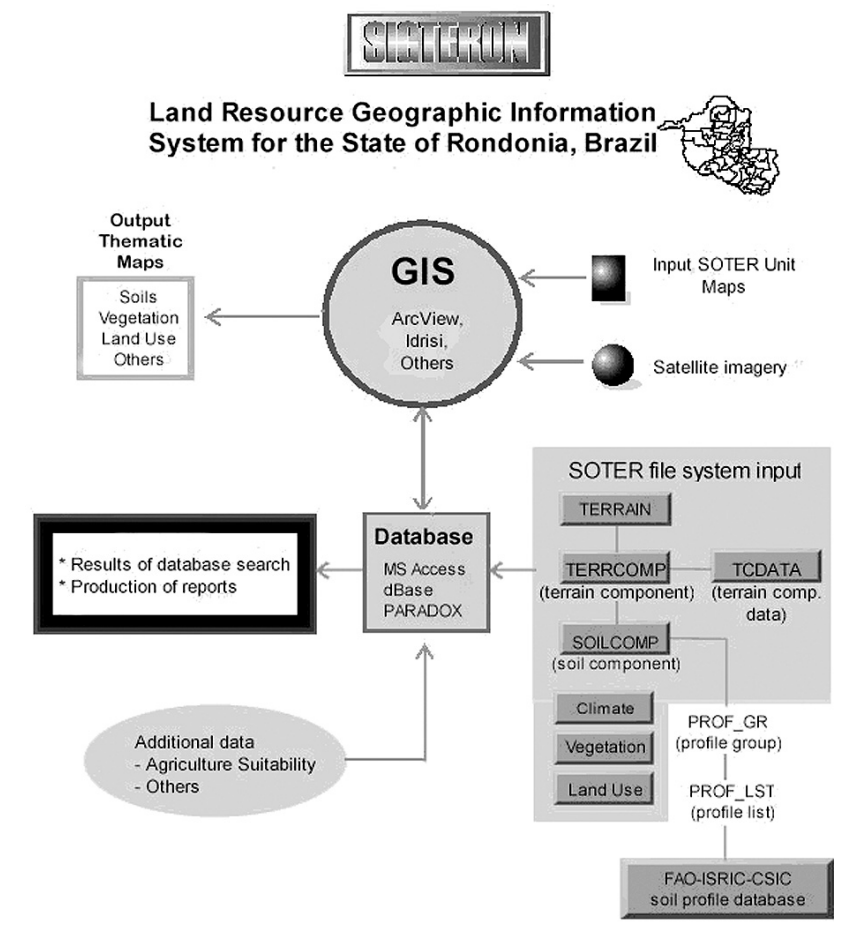

Figure 1 - SIGTERON, the land resource information system for the state of Rondônia.
The physical characteristics of the soils of Rondônia were classified and coded in terms of slope, depth, drainage, temperature regime, moisture regime, moisture holding capacity, texture, presence of coarse materials including gravel, stones and concretions, presence of root restricting horizons and other parameters as detailed in the SOTERON database.

\section{Thumbnail sketches of the SOTRO Units}

Thumbnail sketches were written to summarize the main features of the 244 SOTRO Units mapped at the 1:250,000 scale onto satellite imagery, throughout Rondônia. These formed the body of the report on the land resources of Rondônia, (Cochrane et. al., 1998). The summaries provide the reader with a brief description of the location, area, physiography and topography, altitude, lithology, hydrology, climate, soils, vegetation, land use and agricultural suitability of each SOTRO Unit. They also include cross-section diagrams of the landform and vegetation of the SOTRO Units to help the reader visualize its landscape and to illustrate how the latter separates into "Terrain Components". The soils of the SOTRO Units were described in a little more detail; the main morphological characteristics and fertility of the principal soils of the Terrain Components of the SOTRO Units were individually summarized.

The descriptions of the SOTRO Units are best read in conjunction with an examination of the 1:250,000 soils and land suitability maps. In a sense, the thumbnail descriptions of the SOTRO Units are a type of "encyclopedia" of the principal characteristics of the mapped SOTRO Units of Rondônia. The detailed information is recorded in the SOTERON database, which can be accessed either by using MS Access or Paradox.

\section{Agricultural Climate Studies}

The land resource evaluation of the state started with an assessment of its agricultural climate. Data from 27 meteorological data sets for stations distributed throughout Rondônia were computed in terms of monthly rainfall probablility, Reference Evapotranspiration and their Moisture Availability Indices MAI, using Hargreaves (1977, 1981 and 1994), equations. The latter were used to define dry versus wet months in order to calculate "wet season potential evapotranspiration" regimes as first used by Cochrane and Jones (1981). This and other information was recorded as an integral part of the SOTERON attribute database. It was subsequently integrated with the map files through the assignment of selected meteorological stations to the mapped SOTRO land units; in this way climatic thematic maps can readily be computer generated to visualize the agricultural climatic characteristics of Rondônia.

\section{Soils and Vegetation Studies}

The physical characteristics of the landforms, soils, parent material and vegetation as seen in the field which was supplemented by the digging, examination and sampling of representative soil profile pits, were classified and coded in terms of slope, depth, drainage, temperature regime, moisture regime, moisture holding capacity, texture, presence of coarse materials including gravel, stones and concretions, presence 
of root restricting horizons and other parameters as detailed in the SIGTERON manual. The chemical properties of the soils were evaluated through soil analyses. These were carried out using methods recommended both internationally (Cochrane and Barber, 1993), and by EMBRAPA-SNCLS (1979). The analyses of the soil samples were recorded in both the SDBm file system and additional more comprehensive files. The native vegetation of the region was classified according to the system developed by UNESCO (1973). These physiognomic classes, which are similar to those detailed by Eyre (1966) and summarized by Cochrane et al. (1985), were supplemented with in-field observations.

\section{RESULTS AND DISCUSSION}

\section{Agricultural Climate}

Rondônia can be subdivided into 2 of the broad climatic subregions formulated by Cochrane et al. (1985) as indicated in Table 1 . The northerly half of the state has a more humid "Tropical Humid Hyperthermic" regime with a wet season potential evapotranspiration regime WSPE, of 1061 to $1300 \mathrm{~mm}$, 8 to 9 wet months (with Hargreaves' Moisture Availability Index MAI, greater than 0.33 ), and a wet season mean temperature greater than $23.5^{\circ} \mathrm{C}$. This grades to a drier "Tropical Moderately Humid Hyperthermic" regime with a WSPE regime of 900 to $1060 \mathrm{~mm}, 6-8$ wet months and a wet season mean monthly temperature greater than $23.5^{\circ} \mathrm{C}$, in the southern half of the state. This type of climate is more suitable for arable agriculture. Nevertheless, it should be noted that the climatic patterns of the individual SOTRO units varies quite significantly within these broad sub-regions, and should be taken into account. Further, the southwestern area of Rondônia is more affected by "friagens" (cool southerly winds during the April to September of the year) than the eastern and northerly areas. Altitudinal differences clearly affect temperature regimes; temperatures are significantly cooler on the Serras and high tablelands.

\section{Landforms}

Rondônia was found to have a complex mosaic of peneplain surfaces interspersed with hills derived from the erosion products of elevated and exposed Pre-Cambrian Brazilian shield granites, gneiss and schist, over a large part of the state. Diversifying the landscape, plains and hills formed on extrusions of younger igneous materials are occasionally seen. Further, a range of steep and broken sandstone hills, the Serra dos Pacaas Novas, extends inland from its central western border a little to the north of the city of Guajará Mirím, and extensive, dissected sandstone tablelands, the Chapada dos Parecis covers much of its southeast and eastern regions where the state shares a common border with the state of Mato Grosso. Along a large part of Rondônia's extensive western border, the Guaporé - Mamoré - Madeira river flows northwards following the western exposure of the Pre-
Cambrian Brazilian shield formation. As noted in the introduction, this river is navigable from the capital city Porto Velho. In the south-central sector of Rondônia, an extensive alluvial wetland savanna or "pantanal" shares a common border with Bolivia along the Guaporé River. To the north of the Serra dos Pacaas Novas, lesser hill formations and a complex of peneplains mosaic the otherwise flatter northern region of the state. With such diverse landscapes, soils in terms of both their physical and chemical properties vary significantly from place to place.

The broad characteristics of the landforms, lithology and climate of Rondônia have been summarized in Table 1, and the diversity of the landforms and lithology illustrated by Figure 2 . The landforms follow the SOTER definitions; they have been further subdivided in terms of drainage, presence of rocks and, or stoniness and the broad SOTER lithological "classes". The climate classes follow the agricultural climate classes of Cochrane et al. (1985) for tropical South America. Table I shows that approximately $75 \%$ of the lands of Rondônia have level landforms with slope gradients less than $8 \%$, and a further $21 \%$ has sloping landforms with slopes on average ranging between 8 to $30 \%$. Only a small fraction of the state has steeply sloping lands. Unfortunately, $19 \%$ of the level lands have poor drainage and/or stoniness-rock outcrop problems.

It is evident from Table 1 and especially Figure 2 , that the lithology of Rondônia is complex. It ranges from igneous through metamorphic to sedimentary rock and unconsolidated materials that form the parent materials of the region's soils. Detailed subdivisions into lithological "groups" and in turn "types", were recorded in the files of the SOTERON database for the individual SOTRO units.

Considering the level lands of Rondônia without serious drainage and, or surface rock or stoniness problems, nearly $50 \%$ are found in the more humid parts of Rondônia, the Tropical Humid Hyperthermic climate subregion; only $3 \%$ of the latter are found at altitudes greater than $300 \mathrm{~m}$. In contrast, about $24 \%$ of the flat lands seen in the less humid regions, the Tropical Moderately Humid Hyperthermic climate subregion, are found at altitudes greater than $300 \mathrm{~m}$.

\section{Native Vegetation}

The native vegetation cover of the state ranges from tropical swamp vegetation, wet and dry land savannas (termed "cerrados" in Brazil), semi-deciduous seasonal forests and semievergreen to almost evergreen seasonal forests and the hydroseres of these physiognomic formations, with varying palm populations and other, especially shrub-layer, characteristics. These formations vary not only with soil drainage and flooding, but also with inherent soil fertility conditions. Unfortunately, along the major highways, and especially along the BR-364, most of the original forest has been removed. This has mainly occurred during the past 25 years. Pasture establishment for cattle grazing covers the 


\section{ACTA \\ AMAZONICA}

DIVERSITY OF THE LAND RESOURCES IN THE AMAZONIAN STATE OF RONDÔNIA, BRAZIL. DIVERSIDADE DOS TERRENOS E SOLOS DO ESTADO DE RONDÔNIA, BRASIL. greatest part of the deforested lands, although significant areas are being used for perennial and annual crops.

It was observed that there is a very close relationship between the physiognomic vegetation classes, climate and soil properties. On the well drained soils, the physiognomic vegetation patterns followed their Wet Season Potential Evapotranpiration (WSPE) regimes, as formulated by Cochrane and Jones (1981). As explained by those authors, WSPE regimes provide a proxy estimate of the ambient energy that native vegetation, growing on well drained soils, can take advantage of, during the annual growing cycle. WSPE assumes limited growth during the dry months of the year when soil water is restricted. Nevertheless, as later established statistically by Cochrane (1989), the soil chemical properties of well drained soils will influence the physiognomy of natural vegetation. It was patently evident from the Rondônian studies, that on well-drained soils within a given WSPE regime, there was a close relationship between the height and vigour of the native forests, and the inherent fertility of their soils. Inherent fertility is determined by the mineralogical nature of a soils parent material, which influences its ability to provide plant nutrients over time.

\section{The Soils of Rondônia}

During the course of the field studies, detailed descriptions of 2,914 soil profiles that had been dug throughout the state were selected for recording in the SDBm soil (profile) database (FAO-ISRIC-CSSS, 1995). These profiles had been examined according to FAO criteria. A combination of trenches and auger borings were used and where possible, profiles were dug to a depth of $1.2 \mathrm{~m}$ (or more) and principal horizons were sampled. The exact geographical location of the soil profiles sampled in the field was determined by Geographical Positioning System instruments, and these points were located on the 1:250,000 soil maps as shown in Figure 3. Areas with few or no profiles were either very hilly or alternatively swampy lands with little agriculture potential, best left under their natural vegetation as wildlife reserves.

\section{SoilMaps}

Soil classification maps of Rondônia were completed at the scale of 1:250,000. These maps should more correctly be termed soil "taxonomic" maps. SIGTERON facilitated the production of soil classification maps using the USDA system

Table 1 - Landforms, Drainage, Lithology, Surface Rocks and, or Stoniness and climate of of Rondônia.

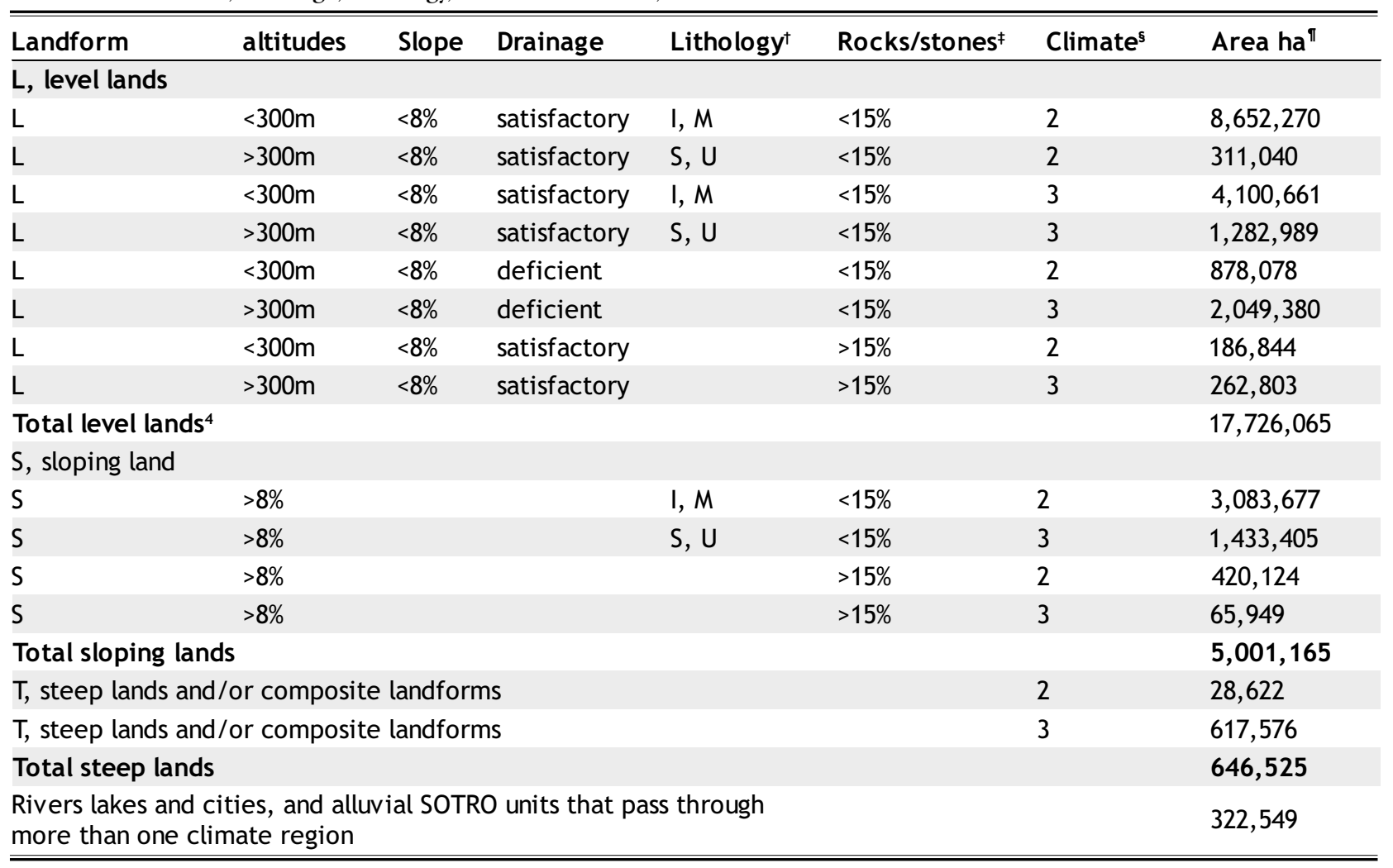

Notes.

+ Lithological classes: I = igneous rock, $\mathrm{M}$ = metamorphic rock, $\mathrm{S}=$ sedimentary rock, $\mathrm{U}=$ unconsolidated rock

₹ Percentage of surface rocks or stones.

$\$$ Climatic subregions: 2 = Tropical Humid Hyperthermic, 3 = Tropical Moderately Humid Hyperthermic

" Estimations of areas were made directly from the database. 
(Soil Survey Staff, 1975), the Brazilian soil classification system (Camargo et al., 1987), the FAO Legend (FAO-UNESCO, 1974), and several more recent updates of those and other systems. This was carried out by linking the attribute criteria corresponding to a given classification system recorded in the SOTERON database with the GIS files delineating the SOTRO land units. An example of a soil taxonomic map of the state has been recorded by Cochrane and Cochrane (2001). In contrast with traditional soil mapping, the methodology facilitates a much more in-depth examination of soils and particularly in terms of their properties, as the basic information about each land or SOTRO unit, can be extracted from the attribute database. This facilitates the compilation of accurate statistical information about the land resources, and data analysis. Following analysis, aggregated information can be depicted in many different ways as thematic maps. A summary of some of the soils features of Rondônia follows:

\section{Soil Physical Properties}

Soil drainage problems: Table 1 shows that approximately $16 \%$ of the level lands of Rondônia have soils with drainage problems. In addition to surface drainage problems, many soils have internal drainage limitations and others, including many of the river terrace and valley floor lands, are subject to annual flooding. In some areas, including the environs of the township of Humaita to the north of Porto Velho, poor soil drainage results in wet land savanna vegetation.

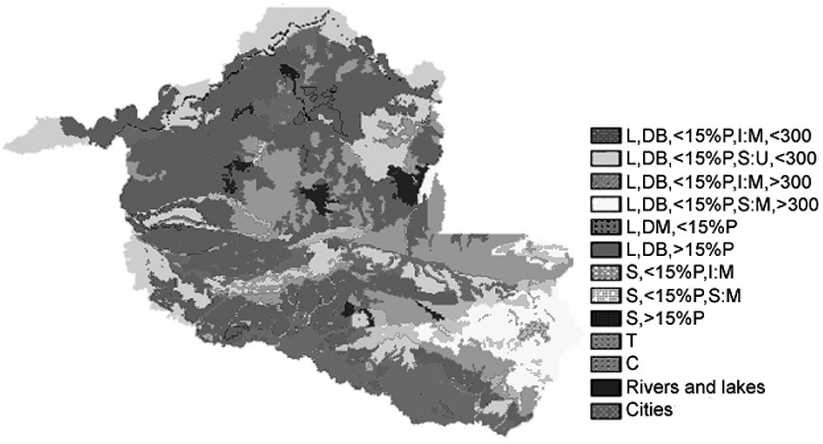

Figure 2 - Landforms, drainage, surface stoniness and lithology of Rondônia.

Map codes: Landform: $\mathrm{L}=$ level lands, $\mathrm{S}=$ sloping lands, $\mathrm{T}=$ steep lands, $\mathrm{C}=$ composite landforms. Drainage classes: $\mathrm{DB}$ $=$ soils with satisfactory drainage, $\mathrm{DM}=$ soils with impeded drainage. Surface stones and, or rocks: $<15 \% \mathrm{P}$ or $>15 \% \mathrm{P}=\%$ of surface stones and, or rocks. Lithological classes: $\mathrm{I}=$ igneous rock, $\mathrm{M}=$ metamorphic rock, $\mathrm{S}=$ sedimentary rock, $\mathrm{U}=$ unconsolidated rock. Height above sea level of flat lands: < 300 or $>300$ in meters.

Soil texture: Only $7 \%$ of Rondônia has light textured soils or soils with lighter textured topsoils. The water holding capacities of these soils are very low, and they often have severe chemical constraints; some only support savanna vegetation.

Table 2 - Exchangeable Cation Analyses of soils with Inherent Fertility Differences Related to Parent Materials

\begin{tabular}{|c|c|c|c|c|c|c|c|c|c|}
\hline \multicolumn{10}{|l|}{$\overline{\text { Profile R01639' }}{ }^{\dagger}$} \\
\hline $\begin{array}{l}\text { Upper boundary } \\
\text { of sample }(\mathrm{cm})\end{array}$ & $\begin{array}{l}\text { Lower boundary } \\
\text { of sample }(\mathrm{cm})\end{array}$ & $\begin{array}{l}\mathrm{pH} \text { in } \\
\text { water }\end{array}$ & ECEC & $\mathrm{Ca}$ & $\mathbf{M g}$ & K & $\mathrm{Na}$ & H & Al \\
\hline 0 & 15 & 6.5 & 6.08 & 4.33 & 1.23 & 0.5 & 0.02 & 0 & 0 \\
\hline 40 & 50 & 6.3 & 6.00 & 3.54 & 2.19 & 0.25 & 0.02 & 0 & 0 \\
\hline 70 & 80 & 5.7 & 4.96 & 2.42 & 2.21 & 0.31 & 0.02 & 0 & 0 \\
\hline \multicolumn{10}{|l|}{ Profile R01550† } \\
\hline $\begin{array}{l}\text { Upper boundary } \\
\text { of sample }(\mathrm{cm})\end{array}$ & $\begin{array}{l}\text { Lower boundary } \\
\text { of sample }(\mathrm{cm})\end{array}$ & $\begin{array}{l}\mathrm{pH} \text { in } \\
\text { water }\end{array}$ & ECEC $\ddagger$ & $\mathrm{Ca}$ & $\mathbf{M g}$ & K & $\mathrm{Na}$ & $\mathrm{H}$ & Al \\
\hline 0 & 15 & 4.7 & 0.94 & 0.10 & 0.03 & 0.04 & 0.01 & 008 & 0.68 \\
\hline 25 & 45 & 4.8 & 0.78 & 0.11 & 0.03 & 0.01 & 0.00 & 0.17 & 0.46 \\
\hline 65 & 80 & 4.9 & 0.75 & 0.17 & 0.07 & 0.01 & 0.00 & 0.13 & 0.37 \\
\hline 110 & 125 & 4.5 & 1.60 & 0.10 & 0.02 & 0.00 & 0.00 & 0.12 & 1.35 \\
\hline \multicolumn{10}{|l|}{ Profile R01581 ${ }^{\dagger}$} \\
\hline $\begin{array}{l}\text { Upper boundary } \\
\text { of sample }(\mathrm{cm})\end{array}$ & $\begin{array}{l}\text { Lower boundary } \\
\text { of sample }(\mathrm{cm})\end{array}$ & $\begin{array}{l}\mathrm{pH} \text { in } \\
\text { water }\end{array}$ & $\mathrm{ECEC}^{\ddagger}$ & $\mathrm{Ca}$ & Mg & $\mathrm{K}$ & $\mathrm{Na}$ & H & Al \\
\hline 0 & 10 & 4.5 & 2.04 & 0.11 & 0.05 & 0.09 & 0.01 & 0.35 & 1.43 \\
\hline 20 & 35 & 4.6 & 1.51 & 0.11 & 0.07 & 0.06 & 0.01 & 0.49 & 0.77 \\
\hline 70 & 85 & 5.0 & 0.70 & 0.14 & 0.05 & 0.01 & 0.01 & 0.12 & 0.37 \\
\hline 110 & 120 & 5.3 & 0.55 & 1.16 & 0.03 & 0.01 & 0.00 & 0.07 & 0.31 \\
\hline
\end{tabular}

+ Analyses extracted from the soil analyses file of the SIGTERON database

${ }^{*}$ Effective cation exchange capacity. Analyses of cations quoted in $\mathrm{cmol}_{c} \mathrm{Kg}^{-1}$ soil (Cochrane and Barber, 1993). 


\section{ACTA AMAZONICA}

DIVERSITY OF THE LAND RESOURCES IN THE AMAZONIAN STATE OF RONDÔNIA, BRAZIL. DIVERSIDADE DOS TERRENOS E SOLOS DO ESTADO DE RONDÔNIA, BRASIL.
Paradoxically, it was seen that many of the heavier (clay) textured soils which have high Al-Fe sesquioxide levels tend to act more like lighter textured soils in-so-far-as their water holding capacities are concerned. On the other hand, because of their well-developed micro structuring, these "oxic" soils are relatively stable, have good drainage properties and are much less "fragile" than implied by some authors (Cochrane et al., 1985).

Soil erosion: During the course of the fieldwork an evaluation was carried out of the actual erosion of lands throughout Rondônia according to the SOTER methodology, and the information recorded as an integral part of the database. In general, soil erosion was not found to be a serious problem, due mainly to the aggregate stability of many of the "oxic" soils. Nevertheless, steep hill slope soils are prone to erosion following deforestation, with the resultant pollution of streams and rivers.

\section{Soil Chemical and Nutrient Properties}

Detailed chemical soil analyses were carried out on most of the soil profile samples collected during the field expeditions; 10,779 sets of analyses were recorded in the database. It is difficult to make generalizations when considering the soil chemical conditions for a region with soils as varied as those found in Rondônia. However, it is interesting to detail a few observations on the chemistry of Rondônia's soils to illustrate the type of problems that exist in some of the soils studied:

Soil acidity, pH: Low $\mathrm{pH}$ levels affect availability of several essential plant elements. Further, a pH less than 5.4 is considered potentially critical, as it provides the necessary soil

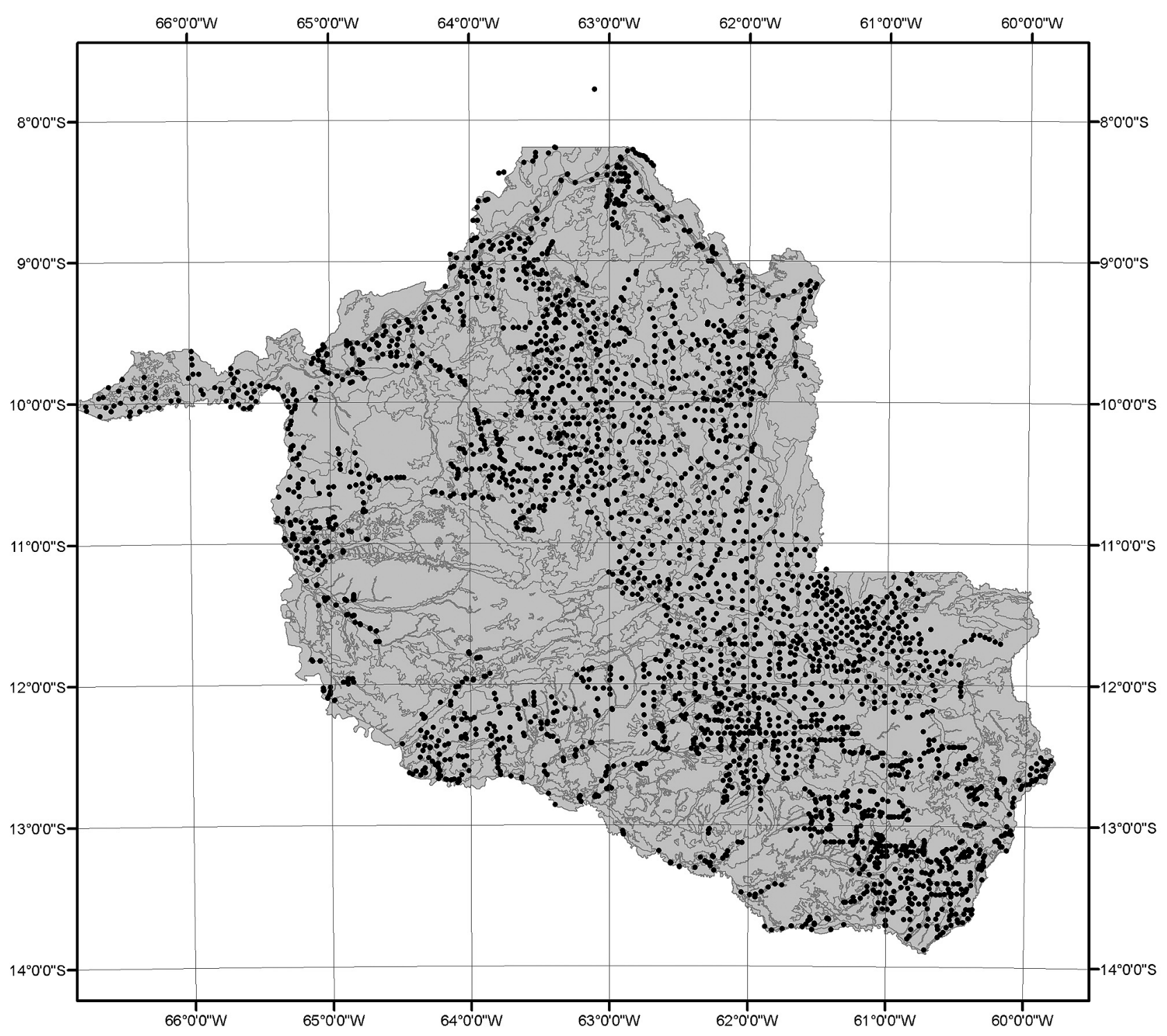

Figure 3 - Location of soil profiles taken during the $2^{\text {nd }}$ ZEE-RO in the state of Rondônia. 
solution environment for Al toxicity problems (Cochrane et al., 1980). It is clear that the majority of the soils of Rondônia have low $\mathrm{pH}$ values; the average of all the topsoil profile samples is 4.96 with a standard deviation of 0.9 . Consequently, about $69 \%$ of soils are below the critical $\mathrm{pH}$ and many of the soils may require liming for effective crop production (Figure 4). It is important to note that although the lowest $\mathrm{pH}$ recorded for a topsoil sample in Rondônia was 3.4, the highest was 8.4. This indicates the variations of the soils found as shown in Figure 4.

A feature of some of the soils of Rondônia, is that occasionally they have "positive delta $\mathrm{pH}$ " values; these are values calculated by taking the difference between $\mathrm{pH}$ determined in $1 \mathrm{M} \mathrm{KCl}$ solution and in water. A positive delta $\mathrm{pH}$ value is a strong indicator of the presence of a substantial "anion exchange capacity" in a soil. Anion exchange capacity is an important and much overlooked feature of some tropical soils; it may be present even in the absence of a positive delta $\mathrm{pH}$ (Cochrane and Souza, 1985). As explained by Cochrane (1991), the development of anion exchange capacity in tropical soils is probably "nature's way" of slowing the degradation of soils by stopping the nitrate leaching process of cations held to the soil surfaces.

Aluminum toxicity: The average value of the Al saturation of the effective cation exchange capacities of the topsoil samples taken during the course of the studies was $34.1 \%$, but with a range of 0 to $92.5 \%$ (Figure 5). As mentioned before, many soils in Rondônia were seen to have high percent aluminum saturation with $\mathrm{pH}$ levels less than 5.4 , a condition potentially toxic for crops. However, the equation developed by Cochrane et al. (1980) for liming tropical acid soils taking into account crop tolerance to high Al levels, could save farmers in Rondônia a lot of money in terms of reducing liming costs, as it has in many other parts of the world (Yost et al. 1991).

Carbon levels: In accordance with the analyses, the organic carbon levels, which are used to indicate soil organic matter contents, are in the medium range in the topsoils but very low in the subsoils; average $1.8 \%$ versus $0.49 \%$. As soil organic matter levels are intimately linked to soil fertility there is a need to conserve the upper horizon of these soils through cultivation practices. It should be noted however, that the determinations were carried out using the Walkley-Black method as adapted by Cochrane and Barber (1993). Unfortunately, this method is affected by free Fe in soils, so care must be used in interpreting results.

Exchangeable cations, calcium, magnesium, potassium and sodium: The majority of the topsoils of the state have exchangeable cation levels in the medium to low range with as often as not, very low subsoil levels. The levels often follow their organic matter levels. The fertility of soils developed in mineral-poor parent materials is undoubtedly related to the organic matter cycle of the original forest cover. In these soils there is a close relationship between organic carbon levels and total exchangeable cations. The average effective cation exchange capacity of the top-soil samples analyzed for Rondônia was a low $3.5 \mathrm{cmol}_{\mathrm{c}} \mathrm{kg}^{-1}$, with a standard deviation of 2.8 (Figure 6).
The levels and especially the ratios of exchangeable $\mathrm{Ca}, \mathrm{Mg}$ and K were examined for the soils and recorded in the database. Cochrane (1989) found an almost perfect correlation between the native vegetation patterns and soil $\mathrm{Ca} / \mathrm{Mg}$ ratios in the savannas of central Brazil. High $\mathrm{Ca} / \mathrm{Mg}$ ratios were seen in some of the better-drained savanna soils in southern Rondônia.

Phosphorus: The available phosphorus levels of the topsoils are predominantly in the lower to medium range and unlikely to sustain crop growth for any length of time without fertilization. However, this is the case of many soils found in other parts of the world with agriculturally productive soils.

Nitrogen: Nitrogen analyses were carried out for the soil profile topsoil samples. Nevertheless, due to the rapid change in nitrogen levels with time and especially on drying (the soil analyses were carried out in Cuiaba in the neighboring state of Northern Mato Grosso), the analyses must be interpreted with considerable caution, as explained by Cochrane and Barber (1993).

With respect to nitrogen in tropical soils with a seasonal rainfall pattern, there is usually a strong release or "flux" of nitrates at the start of the wet season, probably associated with bacterial build-up during the dry season. This was first observed by Hardy (1946). This phenomenon is important in managing crop cultivation, especially to take advantage of the release of nitrogen early in the wet season. It is also a very important part of the leaching mechanism in tropical soils as explained by Cochrane (1991).

Sulfur and trace elements: Analyses were carried out for sulfur and trace elements on a selection of the soil profiles. The ranges of the values found were used to indicate possible potential problems. In other words, if a soil shows a low level of a trace element in relation to the average analytical value, then a potential deficiency problem might be suspected. With respect to sulfur, it was seen that levels tend to follow the organic matter levels; deficiencies may well develop in a few years following deforestation. Zinc levels often appear to be marginal. Consequently, it is probable that zinc deficiencies will occur on soils requiring heavy liming to overcome Al toxic conditions. Of the 460 soil profiles examined for $\mathrm{Mn}$ and $\mathrm{Fe}$, approximately $16 \%$ had levels of exchangeable Mn greater than $2 \mathrm{cmol} \mathrm{kg}^{-1}$, which would be considered high by most standards. Potential Mn toxic conditions were most common in the poorly drained soils. A similar situation was seen with respect to Fe. Poorly drained soils thought suitable for wetland rice growing, should be examined for Fe toxic conditions, preferably in the field using the test developed by Cochrane and Souza (1986).

Soil Parent Material, Inherent Fertility and Native Vegetation

Throughout Rondônia a close relationship was observed between the parent material of the soils and their inherent fertility, as accorded by their chemical analyses. The following three examples of well-drained soils have been taken from the moderately humid southern region of the state, illustrate this effect: 


\section{ACTA AMAZONICA}

DIVERSITY OF THE LAND RESOURCES IN THE AMAZONIAN STATE OF RONDÔNIA, BRAZIL. DIVERSIDADE DOS TERRENOS E SOLOS DO ESTADO DE RONDÔNIA, BRASIL. a) SOTRO Unit No. RO-0133, found on basic igneous rock with moderate to high fertility levels. Example: Profile group RON-082, typical profile RO1639. See Table 2 for the exchangeable cation exchange analyses. These soils support a tall, vigorous forest cover in their virgin state.

b) SOTRO Unit No. RO-0127, found on coarse-grained sandstones, with very low fertility levels. Example: Profile group RON-066, typical profile RO1550. Table 2 records the exchangeable cation exchange analyses. These soils only support a low forest cover in their undisturbed state.

c) SOTRO Unit No. RO-0126, found on fine-grained sedimentary deposits with low fertility levels. Example: Profile group RON-064, typical profile RO1581. The exchangeable cation exchange analyses are shown in Table 2 . These soils support a low to medium height forest in their natural state.

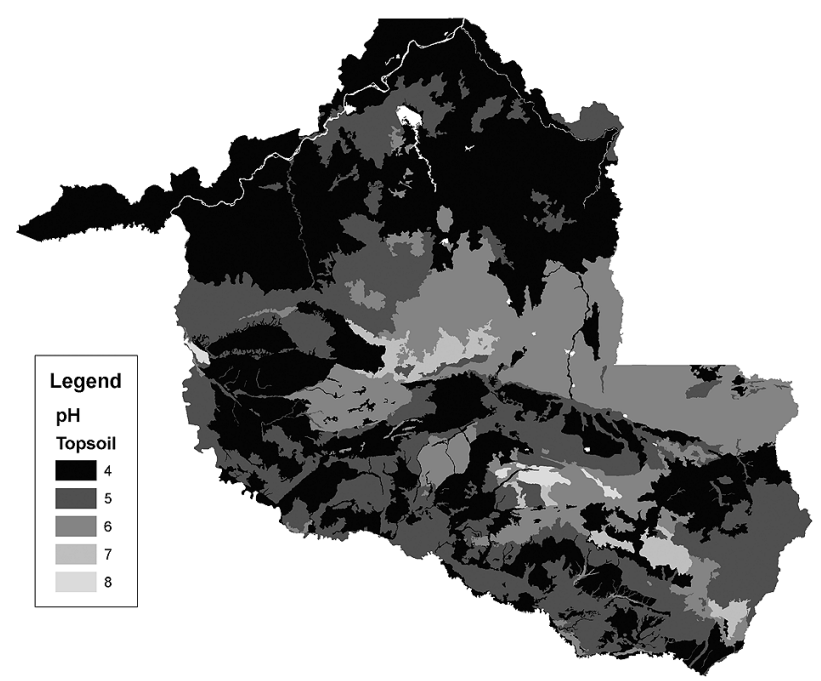

Figure 4 - Distribution of $\mathrm{pH}$ values for topsoils in Rondônia based on soil survey and samples.

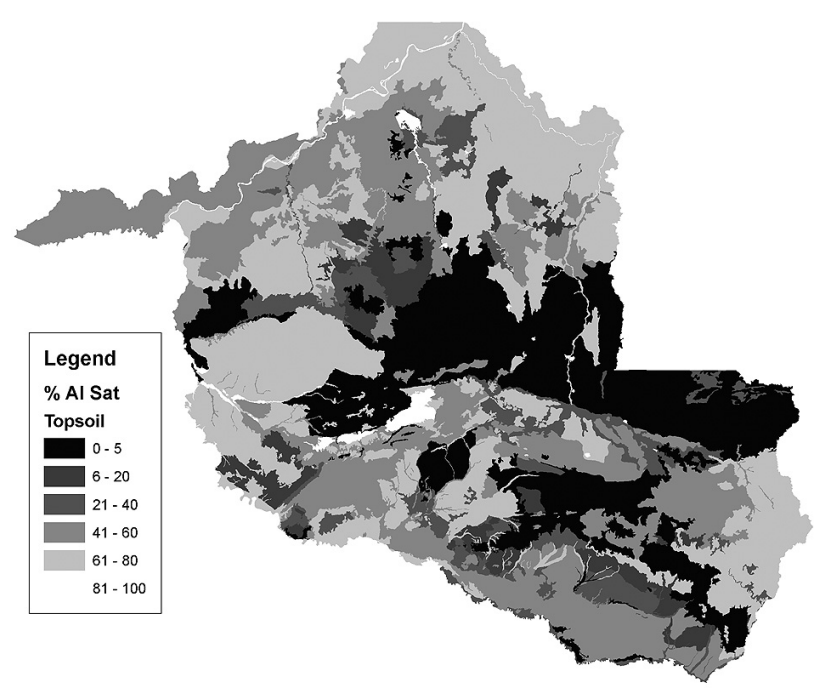

Figure 5 - Percent topsoil aluminum saturation distribution in Rondônia based on soil survey and samples.
It is evident that soils formed on basalts, granites, and gneiss are usually considerably more fertile than those on sandstones and other mineral-poor parent materials. The foregoing observations clearly goes against popular belief originating from early workers studying tropical soils, that parent material was of little importance in determining their fertility.

\section{SUMMARY AND CONCLUSIONS}

The compilation of the SIGTERON computerized system provided a tool for the effective analyses of the wealth of information collected on the land conditions of Rondônia, and a basis for the realistic land resource zoning of that state. It was evident that the diversity of the land conditions found were not apparent, or simply ignored by some authors, discussing the results of past less detailed studies covering Amazonia. This may indicate that small-scale studies, although useful in providing over-all analyses, have often been too generalized to demonstrate the considerable differences in the misnomer "Amazon forest soils".

It is clear even from the very small scale map of Figure 2, that Rondônia has a diverse and complicated mosaic of land and soil conditions. This is patently evident from an examination of the larger scale 1:250,000 scale soil and land suitability maps. The climate of the northern half of the state is significantly more humid than that of the southern half. Landscapes, natural vegetation and soils vary considerably from place to place; the latter in terms of both their physical and chemical properties. It was found that there are substantial areas of the state with almost flat, relatively fertile, well-drained soils that are suitable for sustainable agriculture. Most of these areas are towards the southern half of the state and within easy reach of the well-located BR-364 highway. However these

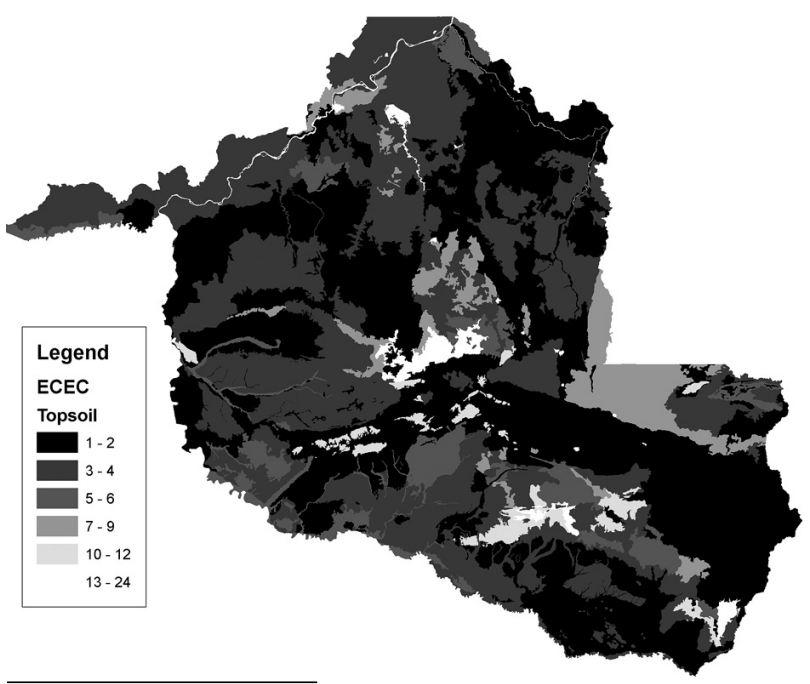

Figure 6 - Effective Cation Exchange Capacity (ECEC in $\mathrm{cmol} \mathrm{km}^{-1}$ ) distribution in Rondônia based on soil survey and samples. 
are interspersed with extensive areas of soils with poor physical and, or chemical conditions.

In-so-far-as the question of the sustainability of Amazon soils to support agriculture is concerned; it is evident that the effective cation exchange capacity of many of the soils found in Rondônia would be considered low. However, these values are not as low as comparable "oxic" soils found in the central cerrados (savanna) region of Brazil (Cochrane 1989), where arable agriculture has been successfully developed. Be this as it may, although the majority of the soils have developed on strongly weathered, mineral-poor parent materials with low cation exchange capacities, quite significant areas have formed from the weathering products of relatively mineral-rich soil parent materials including basalts, granites and gneiss. The latter soils are often well supplied with plant nutrients, and have the capacity to sustain the supply of nutrients over time for crop growth. Many are being, or could be used for successful agricultural and pastoral production. Well-drained soils on flat terrain without other serious physical limitations, but developed on chemically-poor parent materials require heavy dressings of lime and fertilizers for successful agricultural production.

Looking to the past and the reckless removable of Amazonian forests in parts of Rondônia, the study shows that large areas of the state would best have been left under their original forests. Fortunately, the extent of lands usually considered as "fragile" or unsuitable for sustainable agricultural and pastoral usage is not as great as often implied by the popular press. In fact, considering the need for opening up areas of potentially productive lands for human occupation, it would seem on closer examination that a substantial proportion of the lands that have been colonized in Rondônia have potentially productive soils which would justify their more intensive usage under different farming systems, always provided that they are properly managed.

The diversity of the soils found throughout the state should put to rest questions concerning the sustainability of Amazon soils for agricultural usage following deforestation. Many past authors have simply failed to recognize the impress on the inherent fertility of soils attributable to differences in parent materials. The variation in climate has likewise been overlooked. In synthesis, there are very significant differences in land conditions found throughout Amazonia and overgeneralizations are simply spurious. It may be concluded that land resource surveys at the level of detail of the Rondônian study would be warranted in many other parts of the Amazon, for the effective zoning of land resource usage to slow the unnecessary destruction of forests in the future.

\section{LITERATURE CITED}

Budowsky, G. 1976. La conservación del medio ambiente. Conflicto o instrumento para el desarrollo. Ciencia Interamericana 17:2-8.
Camargo, M.N., E. Klamt, and J.H. Kauffman. 1987. Sistema Brasileiro de Classificação de Solos. B. Inf. Soc. Bras. Ci. Solo, Campinas, 12:11-33.

Christian, C.S., S.A. Stewart. 1953. Survey of the KatherineDarwin region, 1946. Land Res.Ser.1. CSIRO, Melbourne, Australia.

Cochrane, T.T. 1980. The methodology of CIAT's land resource study of Tropical America. In: P.G.Buroff and D.B. Morrison (ed.) 4th Int. Symp. on Machine Processing of Remotely Sensed Data and Soil Information Systems and Remote Sensing and Soil Survey. IEEE Catalog. no. $80 \mathrm{CH}$ 1533-9 MPRSD, Purdue University, West Lafayette, Indiana IN. p.227233.

Cochrane, T.T. 1989. Chemical properties of native savanna and forest soils in central Brazil. Soil Sci. Soc. Am. J. 53:139141.

Cochrane, T.T. 1991. Understanding and managing acid soils of tropical South America. In P. Detruuck and F.N. Ponnamperuma (eds.), Rice Production on Acid Soils of the Tropics. Institute of Fundamental Studies, Kandy, Sri Lanka. p.113-132.

Cochrane, T.T.; P.G. Jones. 1981. Savanna, forests and wet season potential evapotranspiration in Tropical South America. Trop. Agric. (Trinidad) 58:185-190.

Cochrane, T.T.; D.M.G. de Souza. 1985. Measuring surface charge characteristics in oxisols and ultisols. Soil Science, 140: 223-229.

Cochrane, T.T.; D.M.G. de Souza. 1986. A field test for ferrous iron and ferric-organic complexes in cerrados soils. Pesq. Agropec. Bras. 21: 327-330.

Cochrane, T.T.; R.G. Barber. 1993. Analisis de Suelos y Plantas Tropicales. Centro de Investigacion Agricola Tropical. British Mission in Tropical Agriculture, Santa Cruz, Bolivia and DFID, London.

Cochrane, T.T.; T.A. Cochrane. 1998. SIGTERON: Sistema de Informação Geográfica para os Terrenos e Solos do Estado de Rondônia, Brasil. Users' manual. Tecnosolo / DHV Consultants BV, Porto Velho, Rondônia.

Cochrane, T.T.; T.A. Cochrane. 2001. The world soils and terrain digital database applied to Amazonian Land studies. Journal of Natural Resources and Life Sciences Education 30:62-70.

Cochrane, T.T., J.G. Salinas, and P.A. Sanchez. 1980. An equation for liming acid mineral soils to compensate crop aluminum tolerance. Trop. Agric. (Trinidad) 57:133-140.

Cochrane, T.T., L.G. Sanchez, L.G. Azevedo; C.L. Carver. 1985. Land in Tropical America. Vol 1, 2 and 3. ISBN 84-89206. CIAT, Cali, Colombia and EMBRAPA, Planaltina, D.F., Brazil.

Cochrane, T.T., T.A. Cochrane, B.H. Wallace-Cochrane; T. Killeen. 2003. Personal Computer Version with Database of the Study Land in Tropical America. Agrotecnologica Amazónica S.A., Casilla 6329, Santa Cruz, Bolivia and Conservation International, Washington. 
Empresa Brasileira de Pesquisa Agropecuaria - Serviço Nacional de Levantamento e Conservação de Solo, EMBRAPA-SNCLS. 1979. Manual de métodos de análises de solos. Rio de Janeiro, Brazil.

Eyre. S.R. 1968. Vegetation and soils: a world picture. 2nd ed. Edward Arnold Publisher Ltd., London.

Food and Agriculture Organization of the United NationsUnited Nations Educational and Scientific Organization, FAO-UNESCO. 1974. Soil map of the world. Vol.1, legend. UNESCO, Paris, France.

Food and Agriculture Organization of the United Nations, FAO. 1988. Soil map of the world. Revised legend. World Soils Resources Report 60, FAO, Rome, Italy.

Food and Agriculture Organization of the United NationsInternational Soil Reference and Information CenterInstitute of Natural Resources and Agro-Biology, FAO-ISRICCSIC. 1995. Multilingual soil database. World Soil Resources Rep. 81. FAO, Rome, Italy.

Goodland, R.J.A.; H.S. Irwin. 1975. Amazon Jungle: Green bell to red desert? Elsevier, Amsterdam, The Netherlands..

Hardy, F. 1946. Seasonal fluctuations of soil moisture and nitrate in a humid tropical climate. Trop. Agric. (Trinidad). 23:40-49.

Hargreaves, G.H. 1977. World Water for Agriculture. Climate, precipitation probabilities and adequacies for rainfed agriculture. Utah State University, Logan, USA.

Hargreaves, G.H. 1981. Simplified method for rainfall intensities. Journal of the Irrigation and Drainage Division, Proceedings of the American Society of Civil Engineers. 107: 281-287.

Hargreaves, G.H. 1994. Defining and using reference evapotranspiration. Journal of Irrigation and Drainage Engineering. 120: 1132-1139.
Irion, G. 1978. Soil fertility in the Amazon rainforest. Naturwissenschaften. 65:515-519.

Soil Survey Staff, 1975. Soil Taxonomy. U.S. Dept. of Agric. Handbook No. 438. Government Printing Office, Washington, D.C., U.S.A.

Tosi, J, Jr. 1974. Desarrollo forestal del tropico Americano frente a otras actividades economicas. In: Renunion Interamericano sobre sistemas de produccion para el tropico. p. II-F1-13. Instituto Interamericano de Cooperacion para la Agricultura, Lima, Peru.

United Nations Educational and Scientific Organization, UNESCO. 1973. Vegetation map of the world. UNESCO, Paris, France.

Van Engelen, J.V.W.P; T.T. Wen. (ed). 1995. Global and national soils and terrain digital databases (SOTER): Procedures manual (Revised edition). UNEP, ISSS, ISRIC, FAO. Rome.

Yost, R.S., T.J. Smyth, S. Itoga; Z.C. Li. 1991. Use of decisionsupport systems for making lime and phosphorus recommendations. In: T.J. Smyth et al. (ed.) Annual meeting of the RISTROP network of Central and South American Scientists, Soil Science. Dept. North Carolina State Univ., Raleigh, NC. 
